\title{
FUNCTION OF THE OMASUM IN SEVERAL RUMINANT SPECIES
}

\author{
R. A. PRINS, R. E. HUNGATE and E. R. PRAST \\ Laboratory of Veterinary Biochemistry, Veterinary Faculty, Utrecht, The Netherlands \\ and Department of Bacteriology, University of California, Davis, California 95616, \\ U.S.A.
}

(Received 23 December 1971)

\begin{abstract}
The main function of the omasum is to represent an arrangement for continuance of the fermentation in all species.

2. The $\mathrm{pH}$ of omasal contents of sheep and cattle is near neutral and the rate of fermentation equals the rate in the rumen.

3. Omasal contents of deer have a lower $\mathrm{pH}$ and show a lower fementation rate when compared with the rumen and small amounts of soluble carbohydrate accumulate, contributing not more than $0.3 \mathrm{~g}$ of glucose to the animal per day.
\end{abstract}

\section{INTRODUCTION}

THE SIGNIFICANCE of the omasum in ruminant digestion has long puzzled students of ruminant physiology and nutrition. The book-like arrangement of the laminae, with intervening uniformly thin layers of digesta, suggests an absorptive function. The absorption of water has been regarded as a possible role for this organ but passage of very liquid digesta from the omasum into the abomasum has been observed (Kameoka \& Morimoto, 1959). Liquid passes from the vestibule along the omasal pillar at the edges of the omasal leaves and empties into the abomasum. Solids accumulate between the leaves, forming a compact mass of digesta particles containing more dry matter than is characteristic of rumen contents.

The omasum lacks the salivary bicarbonate which in the rumen neutralizes the acidic fermentation products. The rather low $\mathrm{pH}$ values found in the omasal contents of deer (Prins \& Geelen, 1971) led to the hypothesis that the acidity would act inhibitory to the growth and fermentation of most rumen bacteria and protozoa in that forestomach. The acidity would not inhibit cellulase activity. Many strains of cellulolytic rumen bacteria accumulate reducing sugars in spent cultures in which fermentation has ceased and the $\mathrm{pH}$ has dropped to about 5.5. Studies of the $\mathrm{pH}$ optimum for mixed rumen bacterial cellulase action indicate that at least some bacterial cellulases possess maximal activity at $\mathrm{pH}$ 's close to 5.5 (Hungate, 1944; Krishnamurti \& Kitts, 1969; Leatherwood, 1965). Maximal activity of the cellulase of Ruminococcus albus occurs between $\mathrm{pH} 5 \cdot 5$ and 6.0 (Leatherwood, 1965). These experiments have also shown that most of the cellulase is adsorbed on the cellulose. Cellulase is adsorbed on the plant particles in rumen contents (King, 1956; Kitts \& Underkofler, 1954; Hungate, 1966). These facts suggested 
that a function of the omasum could be the enzymatic production of soluble carbohydrates from the fibrous particles accumulated between the omasal leaves, when conditions were unfavorable to microbial fermentation and growth.

These possibilities have been tested by examining the concentration and production of soluble carbohydrates in the omasum of grazing sheep (Hungate, 1970). Further experiments have now shown that these results were misleading and that failure of maintaining stringent anaerobic conditions throughout the incubation procedure gave false high values for the sugar production rates in the omasum. In the experiments described in this paper more reliable estimates of the omasal fermentation rates and of the accumulation of soluble sugars were obtained.

\section{MATERIALS AND METHODS}

The sheep (Ovis aries: Dutch Texel breed) and cattle (Bos taurus: Friesian breed) material examined in this study was obtained at the local slaughterhouses. Only the sheep had been fed up to the time of death. The cattle were starved for $24 \mathrm{hr}$ prior to slaughter. The deer in this study were red deer (Cervus elaphus) and fallow deer (Dama dama) and were shot as part of the annual selective hunting program in the Netherlands.

In order to obtain zero-time estimates of the soluble sugar concentrations in the omasum, contents from that stomach were sampled rapidly within $5 \mathrm{~min}$ after the animal was killed and fermentation was stopped by adding ethanol to a final concentration of 70 per cent $(\mathrm{v} / \mathrm{v})$. The insoluble materials were separated by centrifugation, and the carbohydrate contents of the clear supernatant measured with the anthrone method (Trevelyan \& Harrison, 1952) using glucose as a standard. Total reducing substances were determined with the method of Hagedorn \& Jensen (1923) using the procedure of Fujita \& Iwatake (1931) to deproteinize the samples when necessary.

Glucose was determined with the glucose-oxidase method (Biochimica Test Combination; Boehringer \& Soehne, Germany) after taking the clarified ethanol supernatants described above to dryness in a rotary evaporator under reduced pressure at room temperature. The dry residues thus obtained were taken up in small amounts of distilled water and these solutions were treated with equal volumes of $\mathrm{ZnSO}_{4} \cdot 7 \mathrm{H}_{2} \mathrm{O} 5$ per cent and $0.34 \mathrm{~N} \mathrm{Ba}(\mathrm{OH})_{2}$ (Somogyi, 1937, 1945; Henry, 1964) or they were passed through DEAE-Sephadex columns eluting with phosphate buffer $(0.05 \mathrm{M} ; \mathrm{pH} 7 \cdot 0)$. In another procedure the solutions were filtered with suction on a small Buchner funnel provided with a Whatman no. 1 filter paper and a Celite-535 mat. The mat was washed several times with small quantities of distilled water. The filtrate was made up to $50 \mathrm{ml}$ with water and was clarified by pouring it into a 125-ml Erlenmeyer flask containing $2 \mathrm{~g}$ of Amberlite IR-120 $\left(\mathrm{H}^{+}\right)$and $3 \mathrm{~g}$ of Duolite $\mathrm{A}-4\left(\mathrm{OH}^{-}\right)$resins. The mixture was occasionally agitated over a period of 2 hours, and then filtered through Whatman no. $2 \mathrm{v}$ paper (Rendig et al., 1964). The solutions were equally concentrated as compared to the original weight of omasal material represented before the glucose-oxidase assay was carried out. All procedures yielded complete glucose recoveries while in the perchloric acid filtrates as recommended in the procedure for estimating blood glucose, very low recoveries $(0-5$ per cent) of added glucose were obtained.

Cellobiose was either determined according to Halliwell (1965) or with the glucoseoxidase method before and after incubation of the samples with $\beta$-glucosidase (from almonds; Sigma Co., U.S.A.).

Sugars were separated by chromatography on Whatman no. 1 chromatography paper using ethyl acetate-pyridine-water $(8: 2: 1, \mathrm{v} / \mathrm{v})$ as the solvent system (Rendig et al., 1964) or on MN 300 cellulose thin-layer chromatography plates (Macherey-Nagel, Düren, Germany) using formic acid-methyl ethyl ketone-tert.-butanol-water 
(15: $30: 40: 15, \mathrm{v} / \mathrm{v})$ (Vomhof \& Tucker, 1951) as the solvent system. The sugars were detected with orcinol (Bevenue \& Williams, 1951), aniline (McCready \& McComb, 1954), or silver nitrate (Trevelyan et al., 1950) reagents.

The soluble carbohydrate supplied by the omasum was estimated by an in vitro technique. Material between the leaves of the omasum was obtained and within 5 min after death, rapidly mixed under anaerobic conditions with oxygen-free carbon dioxide displacing air in the flask. Subsamples of the mixed material were quickly removed and packed tightly without any included gas space into weighed test tubes, which were quickly gassed out with the carbon dioxide and immediately incubated at $39^{\circ} \mathrm{C}$ in a portable waterbath. After 0 and 15 min of incubation ethanol ( 70 per cent, $v / v$ as final concentration) was added to the duplicate incubations to kill the microorganisms, inactivate the enzymes and precipitate materials other than the low molecular weight carbohydrates. The tubes were later weighed, centrifuged, the supernatant was filtered and the filtrate used for anthrone determinations of carbohydrate or for glucose and cellobiose estimations as described above.

Methane production rates were also assessed in vitro. Rumen and omasum samples were quickly transferred to $50 \mathrm{ml}$ or $25 \mathrm{ml}$ centrifuge tubes, without trapping air. The tubes were quickly gassed out with oxygen-free carbon dioxide and stoppered with recessed butyl rubber stoppers. After 5, 10, and $15 \mathrm{~min}$ of incubation, tubes were removed from the portable waterbath and fermentation was immediately stopped by injecting 10 or $5 \mathrm{ml}$ of $2 \mathrm{~N} \mathrm{NaOH}$ through the stoppers. At the laboratory the gasphase in the tubes was allowed to reach atmospheric pressure by inserting a needle attached to a large glass syringe filled with oxygen-free nitrogen. Samples of $0.5 \mathrm{ml}$ of the gasphase were then withdrawn by means of a $1-\mathrm{ml}$ glass syrine and injected into a gaschromatograph (Becker "Permalyzer", Becker, The Netherlands) to analyze for fermentation gases. The column material consisted of Porapak $Q(80-100 \mathrm{mesh})$ and nitrogen served as the carrier gas at a flow rate of $30 \mathrm{ml} / \mathrm{min}$.

Proportions of the individual acids and $\mathrm{pH}$ values in the samples were determined as described earlier (Prins \& Geelen, 1971).

\section{RESULTS}

Measurements of the omasal $\mathrm{pH}$ in sheep and cattle disclosed that the contents of this stomach are near to neutral (Table 1). This is in contrast with the rather low $\mathrm{pH}$ values found in omasal contents from red deer and fallow deer (Table 2).

The production rates of soluble sugars in omasal contents from sheep or cattle upon incubation under stringent anaerobic conditions are very low (Table 1). It can be seen that only between 30 and $54 \mu \mathrm{g}$ of hexose accumulated per $\mathrm{g}$ of omasal contents (wet weight) per hour of incubation. The erroneous measurements on sheep (nrs. 1, 2 and 3) which were mentioned earlier (Hungate, 1970) are included in Table 1 to allow comparison.

Measurements of the concentration of reducing substances in the omasal contents yield values that are higher than the concentrations of soluble carbohydrates. Only a small fraction of the total soluble carbohydrate is present as glucose (Table 3). The concentration of cellobiose in the omasum is of the same magnitude as the glucose concentration. Upon incubation of ingesta from the omasum of cattle there was no measurable change in either the glucose or cellobiose concentrations (Table 4). Thin-layer chromatography of the concentrated supernatant of omasal contents after treatment with ethanol revealed the presence of other soluble carbohydrates in addition to glucose and cellobiose. Among these 
Table 1-Omasal pH values, concentrations and production rates of soluble CARBOHYDRATES IN THE OMASUM OF SBVERAL RUMINANT SPECIES

\begin{tabular}{|c|c|c|c|c|}
\hline \multicolumn{2}{|c|}{ Animal } & Omasal pH & $\begin{array}{l}\text { Total soluble } \\
\text { sugars* }\end{array}$ & $\begin{array}{c}\text { Production rate of } \dagger \\
\text { soluble sugars }\end{array}$ \\
\hline \multirow[t]{6}{*}{ Sheep } & & - & $0 \cdot 236$ & 0.336 \\
\hline & 2 & - & 0.496 & 0.436 \\
\hline & 3 & - & 0.408 & 0.396 \\
\hline & 4 & $7 \cdot 0$ & 0.252 & 0.036 \\
\hline & 5 & 6.9 & 0.130 & 0.054 \\
\hline & 6 & 6.9 & 0.396 & - \\
\hline \multirow[t]{2}{*}{ Cow } & 1 & $7 \cdot 1$ & 0.397 & 0.037 \\
\hline & 2 & $7 \cdot 0$ & 0.323 & 0.029 \\
\hline \multirow[t]{2}{*}{ Calf } & 1 & $7 \cdot 2$ & 0.450 & 0.035 \\
\hline & 2 & $7 \cdot \overline{1}$ & 0.247 & 0.033 \\
\hline
\end{tabular}

* Determined by the anthrone method and expressed as $\mathrm{mg}$ of hexose $/ \mathrm{g}$ of omasal contents (wet wt.).

$\dagger$ As $\mathrm{mg}$ of hexose produced/g wet omasal contents/hr based on 15-min incubations.

TABLE 2-pH VALUES OF FORESTOMACH CONTENTS OF RED DEER AND FALLOW DEER

\begin{tabular}{|c|c|c|c|}
\hline & $\begin{array}{c}\text { Number of } \\
\text { animals }\end{array}$ & Average pH & $\begin{array}{c}\text { Range of } \\
\text { values }\end{array}$ \\
\hline $\begin{array}{l}\text { Rumen } \\
\text { Omasum }\end{array}$ & $\begin{array}{l}8 \\
8\end{array}$ & $\begin{array}{c}\text { Red deer } \\
5 \cdot 80 \pm 0 \cdot 57 * \\
5 \cdot 11 \pm 0 \cdot 02 * \\
\text { Fallow deer }\end{array}$ & $\begin{array}{l}5 \cdot 20-6 \cdot 55 \\
5 \cdot 00-5 \cdot 72\end{array}$ \\
\hline $\begin{array}{l}\text { Rumen } \\
\text { Omasum }\end{array}$ & $\begin{array}{r}16 \\
9\end{array}$ & $\begin{array}{l}5 \cdot 67 \pm 0 \cdot 12^{*} \\
5 \cdot 15 \pm 0 \cdot 20 \dagger\end{array}$ & $\begin{array}{l}5 \cdot 10-6 \cdot 35 \\
4 \cdot 85-5 \cdot 50\end{array}$ \\
\hline
\end{tabular}

* $†$ Values with different superscripts within a column differ significantly from each other for each species at $P<0 \cdot 05$; mean values \pm standard error of the mean (SE) are given.

Table 3-Soluble sugars and REDUCing substances in OMasal digesta from cows

\begin{tabular}{cccc}
\hline Animal & Total soluble sugars* & Total reducing substances $\dagger$ & Glucose + \\
\hline Cow 1 & 0.397 & 0.730 & 0.033 \\
2 & 0.323 & 0.650 & 0.019 \\
\hline
\end{tabular}

* Determined by the anthrone method and expressed as $\mathrm{mg}$ of hexose/g of omasal contents (wet wt.).

$\dagger$ Determined by the method of Hagedorn \& Jensen and expressed as $\mathrm{mg}$ of glucose/g of omasal contents (wet wt.).

$\ddagger$ Determined by the glucose-oxidase method and expressed as $\mathrm{mg}$ of glucose/g of omasal contents (wet wt.). 
FUNCTION OF THE OMASUM IN SEVERAL RUMINANT SPECIES

Table 4-Glucose and cellobiose in omasal digesta from cows aND RED DEeR

\begin{tabular}{ccccc}
\hline Animal & \multicolumn{2}{c}{$\begin{array}{c}\text { Concentration of } \\
\text { glucose cellobiose }\end{array}$} & \multicolumn{2}{c}{$\begin{array}{c}\text { Production rate of } \\
\text { glucose cellobiose } \dagger\end{array}$} \\
\hline Cow 2 & 0.019 & 0.012 & \multicolumn{2}{c}{ negligible } \\
3 & 0.029 & 0.030 & \multicolumn{2}{c}{ negligible } \\
Red deer 1 & 0.020 & 0.014 & 0.045 & 0.058 \\
2 & 0.037 & 0.021 & 0.050 & 0.055 \\
\hline
\end{tabular}

* Determined by the glucose-oxidase method after removal of interfering substances; expressed as mg of glucose or cellobiose/g of omasal contents (wet wt.).

$\uparrow$ Expressed as $\mathrm{mg}$ of sugar produced/g wet omasal contents/hr based on $15-\mathrm{min}$ incubations.

Table 5-Methane Production rates by RUMinal and omasat digesta from cattle AND TWO SPECIES OF DEER

\begin{tabular}{|c|c|c|}
\hline \multirow[t]{2}{*}{ Animal } & \multicolumn{2}{|c|}{$\begin{array}{c}\text { Methane production in } \\
\text { mmoles } / 100 \mathrm{~g} \text { of wet ingesta } / \mathrm{hr}\end{array}$} \\
\hline & Rumen & Omasum \\
\hline Cow 2 & $1 \cdot 01$ & $1 \cdot 33$ \\
\hline & 1.67 & $1 \cdot 34$ \\
\hline Red deer 1 & 1.63 & - \\
\hline 2 & $1 \cdot 33$ & 1.49 \\
\hline 3 & 1.69 & 1.63 \\
\hline & $1 \cdot 87$ & $2 \cdot 03$ \\
\hline 5 & $1 \cdot 04$ & $1 \cdot 16$ \\
\hline 6 & $1 \cdot 52$ & $1 \cdot 25$ \\
\hline 7 & $1 \cdot 38$ & $1 \cdot 33$ \\
\hline \multirow{3}{*}{$\begin{array}{r}\text { Fallow deer } 1 \\
2 \\
3\end{array}$} & 1.82 & $1 \cdot 30$ \\
\hline & $2 \cdot 34$ & 1.09 \\
\hline & $2 \cdot 25$ & $1 \cdot 10$ \\
\hline \multirow[t]{2}{*}{ Animal } & \multicolumn{2}{|c|}{$\begin{array}{l}\text { Methane production in } \\
\text { mmoles } / 100 \mathrm{~g} \text { of dry ingesta } / \mathrm{hr}\end{array}$} \\
\hline & Rumen & Omasum \\
\hline Cow 2 & $6 \cdot 73$ & 6.65 \\
\hline 3 & $7 \cdot 01$ & 6.92 \\
\hline Red deer 5 & $6 \cdot 23$ & $4 \cdot 57$ \\
\hline 6 & $9 \cdot 21$ & $5 \cdot 52$ \\
\hline 7 & $8 \cdot 11$ & $6 \cdot 11$ \\
\hline Fallow deer 1 & 10.70 & $5 \cdot 33$ \\
\hline 2 & 13.92 & $4 \cdot 90$ \\
\hline
\end{tabular}


sugars were arabinose, xylose, galactose, mannose and rhamnose in approximately equal amounts. It seems likely that the increase in total soluble sugars noted in Table 1 was due to a small increase in the concentrations of one or more of these compounds but this was not tested.

Omasal contents from red deer showed a small but definite increase in the glucose and cellobiose concentrations upon incubation under anaerobic conditions (Table 4). The low $\mathrm{pH}$ values in the deer omasum and the slight accumulation of sugars in the incubation experiments with omasal digesta from these animals suggested a diminished fermentation rate in the omasum of deer as compared with the rumen. Production rates of methane were therefore measured in short-term incubations with ruminal and omasal digesta from cattle and from two species of deer (Table 5). Whereas the rates of methane production in the omasum of cattle and red deer were of the same magnitude as the rumen production rates in these animals, they were lower in the omasum of fallow deer when values were based on wet weights of the ingesta. When values were expressed on the basis of dry matter, omasal methane production rates were lower than those in the rumen contents for both deer species.

\section{DISCUSSION}

Takahashi \& Nakamura (1969) found considerable amounts of reducing materials $(0.2-0.9 \mathrm{mg} / \mathrm{ml})$ in rumen fluids of sheep. Even after passage of the fluids through columns of ion exchange resins, values ranging between 0.1 and $0.4 \mathrm{mg}$ of reducing substances per $\mathrm{ml}$ were obtained. Most of these reducing materials in resin eluates could not be considered as free sugars. Heald (1951) reported earlier that approximately $0.4 \mathrm{mg} / \mathrm{ml}$ of reducing but non-fermentable (for yeast) substances were present in abomasal liquor of a sheep. In our work levels of reducing substances in omasal liquid as determined with the method of Hagedorn and Jensen were of the same order of magnitude (Table 3). It would seem that at least some of these reducing substances present in intestinal fluids are responsible for the low recoveries obtained with the glucose-oxidase method when applied to omasum or rumen fluid samples that were deproteinized with perchloric acid (see Materials and Methods). A number of reducing agents are now known to inhibit the glucose-oxidase method, probably by competing with the peroxidase for the hydrogen peroxide evolved in the conversion of glucose to gluconate by the glucose-oxidase (Bergemeyer \& Bernt, 1965). Among these compounds are ascorbic acid, glutathione, cysteine, sodium bisulfite, sulfides (as found in this work) as well as several substances present in the urine of patients suffering from alcaptonuria or the carcinoid syndrome or in the urine of patients taking drugs such as aspirin or L-dopa. The responsible agents in these cases are potent reducing metabolites such as gentisic acid, homogentisic acid, or 5-hydroxy indole acetic acid (Feldman et al., 1970). When in this study interfering substances were removed from the omasal fluids it became clear that only a small portion of the carbohydrate determined with the anthrone method was 
represented by glucose or cellobiose in the omasal fluid. If there would have been significant cellulase activity under circumstances unsuitable for fermentation in omasal contents as discussed above, these sugars would have been expected to accumulate. The amounts of glucose and cellobiose found are of the same magnitude as the glucose concentrations in the rumen fluids of sheep (Takahashi \& Nakamura, 1969) and cattle (unpublished observations in this study).

Fermentation in the rumen as well as in the omasum proceeds under extremely low levels of soluble sugars and there is no accumulation of these sugars nor a diminished fermentation rate in the omasum of cattle and sheep under normal circumstances. In these animals the omasum serves as an additional retention mechanism for the coarse food particles which subsequently are subjected to further fermentation. A pH near to neutrality in the omasum of domesticated ruminants has been found by other workers as well (von Engelhardt, personal communication) and the concentrations of fermentation end products are lower than in the rumen (Prins, unpublished observations). Absorption of acid fermentation products would prevent the $\mathrm{pH}$ from falling. It might seem that if the leaves and wall of the omasum are absorptive, they should exhibit the papillate structure so often associated with absorption in the rumen and intestine. But considerable mixing of contents occurs in those organs, maintaining high concentrations of nutrients immediately adjacent to the absorptive surface. Under these conditions the area of the absorptive surface limits the rate of absorption. It is doubtful that there is much mixing of the solids between the omasal leaves. If diffusion is the chief mechanism for movement of the acid products from the solids mass to the omasal leaf surface, and if the leaf absorbs so actively that the concentration at the surface is almost zero, greater surface would have no advantage. The smooth surface of the omasal leaves seems appropriate to easier passage of the concentrated mass of digesta particles.

We were able to confirm that the omasum in the Cervidae is not as well developed as in the Bovidae (Cordier, 1894). It is poorly separated from the abomasum and has fewer leaves. The suggestion of a less complete fermentation in deer and the higher fermentation rates found (Prins \& Geelen, 1971) may be due to a more rapid rate of passage of ingesta facilitated by the lesser developed omasal "retention device" in deer. Absorption of fermentation products from the deer omasum by the omasal wall would also be limited with high passage rates and lower $\mathrm{pH}$ values with higher concentrations of volatile fatty acids (VFA's) than in the rumen have been found (Prins \& Geelen, 1971). This makes the conditions unfavorable to microbial fermentation and growth.

From the rates of methanogenesis $(M)$ in the rumen and omasum of three of the red deer (see Table 5) and the proportions of individual VFA's (a, b and c being the percentages of acetate, propionate and butyrate resp.), the rates of total VFA produced ( $=x$ in mmoles $/ 100 \mathrm{~g}$ of dry ingesta $/ \mathrm{hr}$ ) can be calculated using the formula $4 M=2(a+b) x-p x$ derived from the fermentation model presented by Hungate (1966). The hexose $(H)$ fermented in the production of the calculated amounts of acetate $(A)$, propionate $(P)$ and butyrate $(B)$ formed is 
$H=(A+P) / 2+B$. If it is assumed however that microbial growth was taking place and that 16.5 per cent of the carbohydrate used would be converted to cellular material (dry weight) (an average figure according to Baldwin, 1970) then this would amount to $100 / 83.5 H-H=0.197 H$ incorporated into cells. From these figures and using the approximate cell composition as proposed by Hungate (1969) fermentation rates can be calculated for these conditions. From the results (Table 6) it can be seen that even if no microbial growth was taking

Table 6-Percentages of individual VFA and calculated production rates of the TOTAL VFA IN THE RUMEN AND OMASUM IN THREE RED DEER*

\begin{tabular}{|c|c|c|c|c|c|}
\hline \multirow[b]{2}{*}{ Animal } & \multicolumn{3}{|c|}{ Molar $\%$ of individual VFA } & \multicolumn{2}{|c|}{$\begin{array}{l}\text { Calculated production of TVFA } \\
\text { in mmoles } / 100 \mathrm{~g} \text { dry ingesta } / \mathrm{hr}\end{array}$} \\
\hline & Acetate & Propionate & Butyrate & No growth & Assuming growth \\
\hline & \multicolumn{5}{|c|}{ Rumen } \\
\hline 5 & 68.7 & $20 \cdot 8$ & $10 \cdot 5$ & $18 \cdot 11$ & $22 \cdot 63$ \\
\hline 6 & $69 \cdot 4$ & $20 \cdot 4$ & $10 \cdot 2$ & 26.54 & $33 \cdot 19$ \\
\hline 7 & $64 \cdot 2$ & $23 \cdot 7$ & $12 \cdot 1$ & $25 \cdot 16$ & $31 \cdot 39$ \\
\hline & \multicolumn{5}{|c|}{ Omasum } \\
\hline 5 & 85.9 & $9 \cdot 7$ & $4 \cdot 4$ & $10 \cdot 69$ & $13 \cdot 42$ \\
\hline 6 & $90 \cdot 5$ & 6.7 & $2 \cdot 8$ & $12 \cdot 27$ & $15 \cdot 41$ \\
\hline 7 & $83 \cdot 2$ & $10 \cdot 3$ & $6 \cdot 5$ & $14 \cdot 45$ & $17 \cdot 90$ \\
\hline
\end{tabular}

* See Discussion

place in the rumen, the fermentation rates in this organ would still be higher than in the omasum, whether microbial growth in the omasum was taking place or not.

The small sugar production observed in the red deer omasum is of limited value to the animal as it would amount to only $0.24-0.35 \mathrm{~g}$ of glucose/adult animal/day as calculated from the glucose and cellobiose produced in the in vitro experiments (Table 4), from the range of wet weight measurements of the total omasal ingesta of red deer and a minimal estimate of a turnover rate of twice a day. Glucose could be absorbed by the omasal wall while cellobiose or other disaccharides would require hydrolysis prior to absorption further down the alimentary tract.

\section{REFERENCES}

Baldwin R. L. (1970) Energy metabolism in anaerobes. Am. f. Clin. Nutr. 23, 1508-1513. Bergemeyer H. U. \& Bern' E. (1965) Determination with glucose oxidase and peroxidase. In Methods of Enzymatic Analysis (Edited by BERGEMEYER H. U.), pp. 123-130. Academic Press, New York.

Bevenue A. \& Williams K. T. (1951) Further evidence indicating the specificity of the orcinol spray reagent for ketoheptoses on paper chromatography. Arch. Biochem. Biophys. 34, 225-227.

CoRDIER J. (1894) Recherches sur l'anatomie comparée l'estomac des ruminants. Annls Sci. nat. Zool. 16, 1-128. 
Feldman J. M., Kelley W. N. \& Lebovitz H. E. (1970) Inhibition of glucose oxidase paper tests by reducing metabolites. Diabetes 19, 337-343.

Fujita A. \& Iwatake D. (1931) Bestimmung des echten Blutzuckers ohne Hefe. Biochem. Z. 242, 43-60.

HaGedorn H. C. \& Jensen B. N. (1923) Zur Mikrobestimmung des Blutzuckers mittels Ferricyanid. Biochem. Z. 135, 46-58.

Halliwell G. (1965) Hydrolysis of fibrous cotton and reprecipitated cellulose by cellulolytic enzymes from soil micro-organisms. Biochem. F. 95, 270-281.

HeAld P. J. (1951) The assessment of glucose-containing substances in rumen microorganisms during a digestion cycle in sheep. Br. F. Nutr. 5, 84-93.

Henry R. J. (1964) In Clinical Chemistry, Principles and Techniques (Edited by Hoeber Medical Division), p. 637. Harper \& Row, Publishers, Inc., New York.

Hungate R. E. (1944) Studies on cellulose fermentation. I. The culture and physiology of an anaerobic cellulose digesting bacterium. F. Bact. 48, 499-513.

Hungate R. E. (1966) The Rumen and its Microbes, 533 p. Academic Press, New York.

HuNGate R. E. (1969) Ruminal fermentation. In Handbook of Physiology. Section 6: Alimentary Canal. Vol. V: Ruminant Physiology. Chapt. 130, pp. 2725-2745. American Physiological Society, Washington DC.

Hungate R. E. (1970) Interrelationships between the rumen microbiota. In Physiology of Digestion and Metabolism in the Ruminant (Edited by Phillipson A. T.) Oriel Press Ltd., Newcastle-upon-Tyne.

KAMEOKA K. \& MORIMOTO H. (1959) Extent of digestion in the rumen-reticulum-omasum. J. Dairy Sci. 42, 1187-1197.

KING K. W. (1956) Basic properties of the dextrinizing cellulases from the rumen of cattle. Virginia Agr. Expt. Sta. Tech. Bull. 127, 3-16.

KitTS W. D. \& UNDERKOFLER L. A. (1954) Hydrolytic products of cellulose and the cellulolytic enzymes. F. Agr. Food Chem. 2, 639-645.

Krishnamurti C. R. \& KitTs W. D. (1969) Preparation and properties of cellulases from rumen micro-organisms. Can. F. Microbiol. 15, 1373-1379.

LEATHERWOOD J. (1965) Cellulases from Ruminococcus albus and mixed rumen microorganisms. Appl. Microbiol. 13, 771-775.

MCCREADY R. M. \& MCComb E. A. (1954) Quantitative determination of sugars on paper chromatograms by a reflectance method. Analyt. Chem. 26, 1645-1647.

Prins R. A. \& Geelen M. J. H. (1971) Rumen characteristics of red deer, fallow deer and roe deer. $¥$. Wildl. Management 35, 673-681.

Rendig V. V., McComb E. A. \& Hu C. L. (1964) Some nonfermentable free sugars in the leaf-petiole fraction of alfalfa (Medicago sativa). F. Agr. Food Chem. 12, 421-423.

SomogyI M. (1937) A reagent for the copper-iodometric determination of very small amounts of sugar. F. biol. Chem. 117, 771-776.

Somogyi M. (1945) Determination of blood sugar. F. biol. Chem. 160, 69-73.

Takahashi R. \& NaKamura K. (1969) Concentrations of free sugars in sheep rumen fluids. Agr. biol. Chem. 33, 619-621.

Trevelyan W. E., Procter D. P. \& Harrison J. S. (1950) Detection of sugars on paper chromatograms. Nature, Lond. 166, 444-445.

Trevelyan W. E. \& Harrison J. S. (1952) Studies on yeast metabolism. 1. Fractionating and micro-determination of cell carbohydrates. Biochem. F. 50, 298-303.

Vomнof D. W. \& Tucker 'T. C. (1965) The separation of simple sugars by cellulose thin* layer chromatography. F. Chromat. 17, 300-306.

Key Word Index-Omasal function; ruminants; omasal $\mathrm{pH}$; ruminal and omasal methane production; Ovis aries; Bos taurus; Cervus elaphus; Dama dama. 